\title{
Pembuatan Media Uji Mikrobiologi Siap Pakai dari Bahan Baku Lokal Indonesia untuk Pengujian Parameter Angka Lempeng Total Preparation of Microbiologycal Test Media Ready-to-Use from Indonesian Local Raw Material for Total Plate Count Parameters
}

\author{
Eddy Sapto Hartanto dan Santi Ariningsih \\ Balai Besar Industri Agro \\ Jl. Ir. H. Juanda No. 11, Bogor 16122 \\ eddy_bbia@yahoo.com
}

\section{Riwayat Naskah:}

Diterima 10, 2018

Direvisi 11, 2018

Disetujui 12, 2018

\begin{abstract}
ABSTRAK: Saat ini kebutuhan media uji Plate Count Agar (PCA) produk impor, yang harganya relatif mahal. Diperlukan PCA produk lokal berbahan baku lokal Indonesia untuk mengurangi beban biaya uji laboratorium yang membutuhkan. Oleh karena itu, perlu dilakukan penelitian pembuatan formulasi media PCA berbahan baku lokal, terutama bahan tepung agar-agar. Formulasi yang dilakukan adalah penggunaan bahan tepung agar-agar lokal dengan Gel Strenght (GS) 800, 900 dan $1000 \mathrm{gr} / \mathrm{cm}^{2}$, serta agar-agar kertas yang dibuat di laboratorium. Hasil analisis viskositas, $\mathrm{pH}$ dan pengamatan secara visual agaragar kertas yang dibuat, untuk uji coba pendahuluan masih belum sesuai sebagai bahan formulasi pembuatan PCA, namun untuk agar-agar GS 800, GS 900 dan GS $1000 \mathrm{gr} / \mathrm{cm}^{2}$ memenuhi persyaratan SNI 2802:2015 (SNI Tepung Agar-agar) dan memenuhi persyaratan spesifikasi agar-agar untuk keperluan uji mikrobiologi berdasarkan persyaratan Indian Standard (1973). Sedangkan uji T-test pada tingkat signifikansi $5 \%(0,05)$ atau dengan tingkat kepercayaan $95 \%$, pada analisis produk PCA berbahan baku agar-agar lokal dengan GS $800 \mathrm{gr} / \mathrm{cm}^{2}$, dengan pembanding PCA komersial (import) menunjukkan bahwa, formula I ( bahan baku agar-agar GS $800 \mathrm{gr} / \mathrm{cm}^{2}$ ), tidak berbeda nyata dibandingkan dengan PCA komersial pada uji penumbuhan biakan murni E. coli, baik konsentrasi rendah maupun medium, sehingga formula I, direkomendasikan sebagai formula terbaik, dibandingkan dengan formula lainnya.
\end{abstract}

Kata kunci: rumput laut Indonesia, formulasi, tepung agar-agar, PCA

ABSTRACT: Currently the need for PCA test media comes from imported products, which are relatively expensive. Local PCA from local Indonesian products is needed to reduce the burden of testing costs for laboratories in need. Therefore, it is necessary to do research on making Indonesian-based PCA media formulations, especially agar powder. The formulation employed was the use of local agar ingredients with Gel Strength (GS) $800 \mathrm{gr} / \mathrm{cm}^{2}, 900 \mathrm{gr} / \mathrm{cm}^{2}$ and 1000 $\mathrm{gr} / \mathrm{cm}^{2}$, as well as gel agar that was made in the laboratory. The result of viscosity analysis, $\mathrm{pH}$ and visual observation of gel agar of paper made, for preliminary trial still not suitable as material of PCA manufacture formulation, but for agar of GS $800 \mathrm{gr} / \mathrm{cm}^{2}$, GS $900 \mathrm{gr} / \mathrm{cm}^{2}$ and GS $1000 \mathrm{gr} / \mathrm{cm}^{2}$ fulfill requirement of SNI 2802: 2015 (SNI Agar Flour) and meets the requirements of the agar specification for the purposes of microbiological test based on the requirements of Indian Standard (1973). While the T-test, for comparative analysis using commercial PCA, showed that Formula I (using GS $800 \mathrm{gr} / \mathrm{cm}^{2}$ agar ingredients) was not significantly different from that of commercial PCA in E-coli culture, either low or medium concentrations, so that the formula I, can be recommended as the best formula, compared with other formulas.

Keywords: Indonesian seaweed, formula, agar powder, PCA 


\section{Pendahuluan}

Indonesia merupakan salah satu negara kepulauan yang memiliki panjang pantai terbesar di dunia, panjang pantai kepulauan Indonesia mencapai $81.000 \mathrm{~km}$, Berdasarkan data Kementerian Kelautan dan Perikanan, Indonesia memiliki luas area untuk kegiatan budidaya rumput laut mencapai 769.452 ha, tetapi pengembangan budidaya rumput laut baru memanfaatkan lahan seluas 384.733 ha atau $50 \%$ dari luas areal potensial (Direktorat Jenderal Perikanan Budidaya, 2013). Jenis rumput laut yang dikembangkan di Indonesia antara lain seperti Kappaphycus alvarezii (cottonii), Eucheuma denticulatum (spinosum) dan Gracilaria sp. Produksi rumput laut Indonesia jenis E. cottonii pada tahun 2013 menempati urutan pertama dunia sebanyak 8,3 juta ton. Untuk rumput laut jenis Gracillaria sp., pada 2013 Indonesia menempati urutan kedua setelah China, dengan produksi sebesar 975 ribu ton (Ansori 2015).

Pemanfaatan rumput laut sebagai bahan baku produk yang lebih bermanfaat dan bernilai ekonomis cukup besar. Berbagai jenis produk yang dapat dibuat menggunakan bahan baku rumput laut antara lain agar-agar, jelly food, manisan dan campuran makanan seperti burger dan lain-lain. Produk agar-agar yang berasal dari bahan baku rumput laut dapat digunakan sebagai bahan baku utama sebagai media untuk pengujian mikrobiologi, sehingga rumput laut memiliki manfaat yang lebih baik dan bernilai ekonomi yang cukup tinggi.

Dalam pengujian mutu suatu bahan pangan diperlukan berbagai uji yang mencakup uji fisik, uji kimia, uji mikrobiologi, dan uji organoleptik. Uji mikrobiologi merupakan salah satu uji yang penting, karena selain dapat menduga daya tahan simpan suatu makanan, juga dapat digunakan sebagai indikator sanitasi makanan atau indikator keamanan makanan. Pengujian mikrobiologi diantaranya meliputi uji kuantitatif untuk menentukan mutu dan daya tahan suatu makanan, uji kualitatif bakteri patogen untuk menentukan tingkat keamanannya, dan uji bakteri indikator untuk mengetahui tingkat sanitasi makanan tersebut (Fardiaz, 1993).

Kebutuhan media uji pada laboratorium mikrobiologi untuk keperluan pengujian parameter cemaran mikrobiologi ada kecenderungan semakin meningkat, sejalan dengan pertumbuhan industri makanan dan minuman yang semakin meningkat, disamping itu adanya pemberlakuan Standar Nasional Indonesia (SNI) wajib bagi industri bahan makanan dan minuman, seperti air minum dalam kemasan, kakao bubuk, gula kristal rafinasi, tepung terigu sebagai bahan makanan dan produk makanan olahan lainnya seperti biskuit, mi instan dan kopi instan. Adanya pemberlakuan SNI wajib tersebut, pada pelaksanaan kegiatan produksi, setiap industri yang memproduksi komoditi atau jenis produk yang ber-SNI wajib, maka setiap produsen wajib memiliki laboratorium mikrobiologi yang dapat menguji parameter cemaran mikrobiologi, khususnya cemaran mikrobiologi yang disyaratkan pada SNI yang berlaku, seperti pengujian parameter angka lempeng total (ALT). Untuk pengujian ALT diperlukan media uji plate count agar (PCA).

Melihat hal tersebut, maka kebutuhan media uji untuk pengujian parameter mikrobiologi akan semakin meningkat, karena media uji tersebut, disamping dibutuhkan oleh produsen produk yang SNI wajib, juga dibutuhkan oleh laboratorium penguji eksternal sebagai dampak dari kewajiban industri yang disamping menguji di internal juga diwajibkan untuk menguji pada laboratorium eksternal yang terakreditasi. Sampai saat ini kebutuhan media uji yang digunakan oleh laboratorium seperti PCA yang digunakan untuk pengujian parameter angka lempeng total sebagian besar berasal dari impor, yang harganya relatif mahal, sebagai contoh harga plate count agar produk impor merek tertentu mencapai Rp 1.250 .000 per 500 gram atau Rp 2.5 juta per kg.

Biaya tersebut relatif cukup mahal bila dibandingkan dengan bahan baku agar-agar yang relatif murah, per kilo hanya sekitar Rp 145.000,sehingga bila bahan media untuk pengujian mikrobiologi khususnya ALT, menggunakan bahan baku agar-agar yang dapat diproduksi di dalam negeri dan ditambah bahan lainnya sebagai bahan pengisi yang dapat diperoleh di dalam negeri juga, maka akan dapat menghemat biaya uji yang cukup banyak.

Dengan adanya permasalahan tersebut, maka dilakukan penelitian pembuatan media PCA siap pakai yang menggunakan bahan baku dan bahan penolong yang berasal dari bahan lokal Indonesia. sehingga akan berdampak positif bagi laboratorium yang memerlukannya, minimal dapat mengurangi biaya pembelian PCA yang dibutuhkan oleh laboratorium pengujian profesional maupun laboratorium industri makanan dan minuman yang memang dituntut harus dapat melakukan pengujian mikrobiologi, khususnya parameter angka lempeng total.

\section{Bahan dan Metode}

\subsection{Bahan}

Bahan yang digunakan dalam penelitian ini adalah rumput laut Gracillaria sp. (digunakan untuk uji coba permulaan pembuatan agar-agar), akuades, agar-agar kertas, agar-agar lokal dengan Gel Strenght (GS) 800, 900 dan $1000 \mathrm{gr} / \mathrm{cm}^{2}$, PCA standar, NA standar, EMBA Standar, bacteria standard, peptone dillution fluid (PDF), sukrosa, kasein, yeast extract, 
dekstrosa, etanol 95\%, laktosa, bacto beef extract, Trypton BPW (Buffer Peptone Water), dan akuades.

\subsection{Alat}

Peralatan yang digunakan adalah cawan petri, tabung reaksi, gelas piala, pipet gondok, tabung Durham, cetakan, kertas saring, erlenmeyer, gelas ukur, pipet volume, tabung reaksi, autoklaf, cawan petri, timbangan analitik, pisau, hot plate, pengaduk, magnetic stirer, blender, jarum ose dan mikropipet dan alat pendukung lainnya.

\subsection{Metode}

Penelitian ini dilakukan dalam 2 tahap, yaitu tahap 1 penelitian pendahuluan dan tahap 2 penelitian utama. Pada tahap 1 dilakukan pembuatan agar-agar kertas. Pada tahap penelitian 2 dilakukan penelitian tentang pembuatan media uji mikrobiologi siap pakai dan pengujian produk yang dihasilkan, dibandingkan dengan produk PCA komersial

\subsubsection{Pembuatan agar-agar kertas}

\subsubsection{Pencucian dan sortasi}

Pencucian rumput laut dilakukan menggunakan air tawar sampai bersih. Kotoran yang menempel seperti pasir, karang, lumpur dan rumput laut jenis lain dipisahkan atau hilangkan.

\subsubsection{Perendaman dan pemucatan}

Perendaman dilakukan agar rumput laut menjadi lunak, sehingga proses ekstraksi nantinya dapat berjalan dengan baik. Caranya rumput laut direndam dalam air murni sebanyak 20 kali berat rumput laut selama 3 hari. Setelah itu pemucatan dilakukan dengan direndam dalam larutan kaporit $0,25 \%$ atau larutan kapur tohor $5 \%$ sambil diaduk, setelah 4-6 jam, rumput laut dicuci kembali selama 3 jam untuk menghilangkan bau kaporit atau kapur. Rumput laut yang telah bersih dan pucat dikeringkan selama 2 hari.

\subsubsection{Pencucian}

Pencucian dilakukan untuk memastikan rumput laut bersih dan terbebas dari berbagai kotoran.

\subsubsection{Pemasakan}

Pemasakan rumput laut dilakukan dengan penambahan air sebanyak 40 kali berat rumput laut dan dilakukan selama 1-2 jam. Setelah mendidih $\left(90-100^{\circ} \mathrm{C}\right)$, setelah mendidih dilakukan penyaringan, akan diperoleh filtrat dan ampas, filtrat ditampung dalam wadah, dan ampasnya dipanaskan kembali, disaring dan filtratnya dicampur dengan filtrat pertama.

Filtrat yang diperoleh, selanjutnya direbus dan ditambahkan $\mathrm{KOH}$ 3\% dari berat rumput laut awal, setelah mendidih, angkat, dicetak didinginkan dan dibiarkan 1 malam agar menjendal, selanjutnya potong-potong, dipres dan dikeringkan, diperoleh agar-agar kertas (Sudariastuty, 2011).

\subsubsection{Pembuatan media uji mikrobiologi}

Pada tahap ini dilakukan penelitian tentang pembuatan media uji mikrobiologi siap pakai dan pengujian produk yang dihasilkan, dibandingkan dengan produk PCA komersial. Proses pembuatan formulasi PCA dapat disajikan pada Gambar 1.

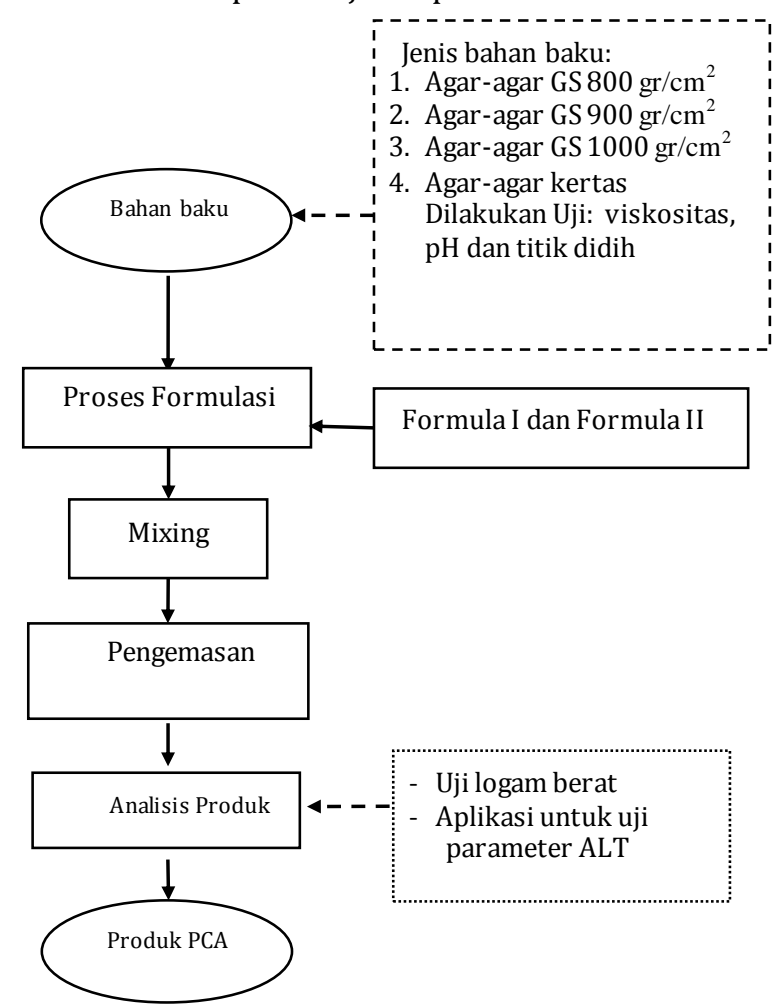

Gambar 1. Diagram alir metode penelitian pembuatan PCA menggunakan bahan baku lokal

\subsubsection{Analisis bahan baku}

Untuk memastikan kualitas bahan baku agaragar yang digunakan pada pembuatan formulasi PCA, terlebih dahulu dilakukan analisis viskositas, $\mathrm{pH}$, titik didih dan pengujian sesuai dengan persyaratan SNI 2802:2015,

\subsubsection{Analisis formulasi PCA}

Hasil terbaik dari bahan baku yang memenuhi persyaratan, baik fisik, kimia, maupun organoleptik, selanjutnya digunakan sebagai pertimbangan 
dalam formulasi PCA. Untuk memastikan PCA hasil formulasi, yaitu formulasi I terdiri atas : tryptone $28,5 \%$, yeast ektrak $14,4 \%$, glukosa $5,7 \%$ dan agaragar GS 800 dan $900 \mathrm{gr} / \mathrm{cm}^{2}$ 51,4\%. Sedangkan formula II terdiri dari yeast ekstrak 13,1\%, peptone 21,7\% dan agar-agar GS 800 dan $900 \mathrm{gr} / \mathrm{cm}^{2}$ 65,2\%. Untuk melihat efektifitas kemampuan agar-agar yang digunakan sebagai bahan baku, digunakan agar-agar GS $800 \mathrm{gr} / \mathrm{cm}^{2}$ dan GS $900 \mathrm{gr} / \mathrm{cm}^{2}$ karena mempunyai kualitas gel strenght yang lebih baik, sehingga hanya dua konsentrasi ini yg dipilih untuk pembuatan formulasi PCA. Selanjutnya formula PCA yang diperoleh dilakukan uji T-test (uji beda nyata) untuk penumbuhan biakan bakteri murni E. coli terhadap produk PCA komersial yang sudah beredar dan digunakan secara umum di Laboratorium Mikrobiologi, Balai Besar Industri Agro, Bogor.

\subsubsection{Uji pendahuluan untuk menentukan konsentrasi bakteri low dan medium}

Biakan bakteri E. coli yang berumur 24 jam dalam Brain Heart Infusion Broth (BHIB) $10 \mathrm{ml}$ dipipet masing masing $1 \mathrm{ml}$ ke dalam cawan petri dan BPW $9 \mathrm{ml}$ (sebagai pengenceran 10-1). Pipet 1 $\mathrm{ml}$ dari pengenceran 10-1 pada poin 1 diatas masing masing $1 \mathrm{ml}$ ke dalam cawan petri dan BPW $9 \mathrm{ml}$ (sebagai pengenceran 10-2). Lakukan pengenceran sampai dengan $10^{-8}$. Tuang semua cawan petri dari tiap pengenceran $10^{\circ}$ sampai dengan 10-8 dengan medium PCA komersil, lalu inkubasikan pada suhu $30{ }^{\circ} \mathrm{C}$ selama 72 jam. Lakukan pengamatan jumlah bakteri pada tiap cawan petri. Didapatkan hasil pengamatan sebagai berikut:

Pengenceran $10^{0}-10^{-6}=>300 \mathrm{koloni} / \mathrm{ml}$

Pengenceran $10^{-7}=201 \mathrm{koloni} / \mathrm{ml}$

Pengenceran $10^{-8}=26 \mathrm{koloni} / \mathrm{ml}$

\subsubsection{Uji angka lempeng total untuk konsentrasi bakteri low}

Setelah diketahui jumlah koloni yang didapat dari uji pendahuluan maka dibuat 1 konsentrasi bakteri Low sebanyak \pm 26 koloni $/ \mathrm{ml}$ dan jumlah bakteri Medium sebanyak \pm 100 koloni $/ \mathrm{ml}$. Konsentrasi bakteri Low dibuat dengan cara melakukan pengenceran dari $10^{-7}$ (pengenceran diambil sebanyak $1 \mathrm{ml}$ dari $10^{-7}$ untuk mendapatkan koloni sebanyak \pm 26 koloni).

Pipet masing masing konsentrasi bakteri Low sebanyak $1 \mathrm{ml}$ ke dua buah cawan petri sebanyak 7 kali ulangan. Tuang semua cawan petri tersebut dengan menggunakan media GS $800 \mathrm{gr} / \mathrm{cm}^{2}$ formula I. Lakukan pemipetan $1 \mathrm{ml}$ ke dua buah cawan petri sebanyak 7 kali ulangan untuk dituang dengan masing-masing medium GS $800 \mathrm{gr} / \mathrm{cm}^{2}$ formula II, GS $900 \mathrm{gr} / \mathrm{cm}^{2}$ formula I GS $900 \mathrm{gr} / \mathrm{cm}^{2}$ formula II dan PCA komersil dengan menggunakan konsentrasi bakteri Low. Inkubasi semua cawan petri pada suhu $30{ }^{\circ} \mathrm{C}$ selama 72 jam. Amati dan hitung jumlah koloni yang tumbuh.

\subsubsection{Uji angka lempeng total untuk konsentrasi bakteri medium}

Konsentrasi bakteri medium dibuat dengan cara melakukan pengenceran dari $10^{-6}$ (pengenceran diambil sebanyak $0,5 \mathrm{ml}$ dari $10^{-7}$ untuk mendapatkan koloni sebanyak \pm 100 koloni). Pipet masing-masing konsentrasi bakteri Medium sebanyak $1 \mathrm{ml}$ ke dua buah cawan petri sebanyak 7 kali ulangan. Tuang semua cawan petri tersebut dengan menggunakan media GS $800 \mathrm{gr} / \mathrm{cm}^{2}$ formula I.

Lakukan pemipetan $1 \mathrm{ml}$ ke dua buah cawan petri sebanyak 7 kali ulangan untuk dituang dengan masing masing medium GS $800 \mathrm{gr} / \mathrm{cm}^{2}$ formula II, GS $900 \mathrm{gr} / \mathrm{cm}^{2}$ formula I. GS $900 \mathrm{gr} / \mathrm{cm}^{2}$ formula II dan PCA komersil dengan menggunakan konsentrasi bakteri Low. Inkubasi semua cawan petri pada suhu $30{ }^{\circ} \mathrm{C}$ selama 72 jam. Amati dan hitung jumlah koloni yang tumbuh.

\section{Hasil dan Pembahasan}

\subsection{Analisis kualitas tepung agar-agar}

Hasil analisis kualitas tepung agar-agar yang digunakan sebagai bahan baku PCA disajikan pada Tabel 1. 
Citation: Hartanto, E. S., dan Ariningsih, S. (2018) Pembuatan Media Uji Mikrobiologi Siap Pakai dari Bahan Baku Lokal Indonesia untuk Pengujian Parameter Angka Lempeng Total. Warta IHP, 35(2), 68-73

Halaman | 72

Tabel 1

Hasil analisis kualitas tepung agar-agar GS $800 \mathrm{gr} / \mathrm{cm}^{2}, \mathrm{GS} 900 \mathrm{gr} / \mathrm{cm}^{2} \mathrm{dan} \mathrm{GS} 1000 \mathrm{gr} / \mathrm{cm}^{2}$

\begin{tabular}{|c|c|c|c|c|c|c|c|}
\hline \multirow[b]{2}{*}{ No } & \multirow[b]{2}{*}{ Parameter } & \multirow[b]{2}{*}{ Sat } & \multicolumn{5}{|c|}{ Hasil uji } \\
\hline & & & SNI 2802:2015 & *) Spec. Indi. Std & GS 800 & GS 900 & GS 1000 \\
\hline 1. & Organoleptik & - & $\min 7$ & - & 8 & 8 & 8 \\
\hline 2. & Air & $\%$ & maks 22 & - & 16.9 & 14.2 & 12.8 \\
\hline 3. & Air $105^{\circ} \mathrm{C} 5 \mathrm{jam}$ & $\%$ & Maks & maks 20 & 15.6 & 12.8 & 11.4 \\
\hline 4. & Abu & $\%$ & maks 6.5 & maks 6.5 & 1.25 & 1.44 & 1.11 \\
\hline 5. & Abu tak larut dalam asam & $\%$ & maks 0.5 & maks 1.0 & 0 & 0 & 0 \\
\hline 6. & Pati & $\%$ & Negatif & & negatif & negatif & negatif \\
\hline 7. & Gelatin dan protein & $\%$ & Negatif & negatif & negatif & negatif & negatif \\
\hline 8. & Absorpsi air & $\%$ & $\min 5$ kali & & 13 kali & 13 kali & 14 kali \\
\hline 9. & Benda asing tidak larut dalam air & $\%$ & maks 1 & maks 1 & 0.10 & 0.23 & 0.14 \\
\hline 10 & Kehalusan (lolos saringan 60 mesh) & $\%$ & $\min 80$ & - & 100 & 100 & 100 \\
\hline 11. & Cemaran logam : & & & & & & \\
\hline a. & Timbal $(\mathrm{Pb})$ & $\mathrm{mg} / \mathrm{kg}$ & maks 3 & maks 10 & $<0.031$ & $<0.031$ & $<0.031$ \\
\hline b. & Kadmium & $\mathrm{mg} / \mathrm{kg}$ & maks 1 & - & $<0.004$ & $<0.004$ & $<0.004$ \\
\hline c. & Timah (Sn) & $\mathrm{mg} / \mathrm{kg}$ & maks 40 & - & $<0.8$ & $<0.8$ & $<0.8$ \\
\hline d. & Raksa (Hg) & $\mathrm{mg} / \mathrm{kg}$ & maks 1 & - & $<0.005$ & $<0.005$ & $<0.005$ \\
\hline 12. & Arsen (As) & $\mathrm{mg} / \mathrm{kg}$ & maks 3 & Maks 3 & $<0.013$ & $<0.013$ & $<0.013$ \\
\hline
\end{tabular}

Pembuatan agar-agar kertas telah berhasil dilakukan, namun dari hasil pengamatan uji viskositas, $\mathrm{pH}$ dan pengamatan secara visual. Hasil analisis viskositas agar-agar kertas antara 65 - 68 $\mathrm{cP}$, lebih rendah dibandingkan dengan tepung agaragar yang mencapai 88 - 172 pada konsentrasi 14 gram/liter, untuk $\mathrm{pH}$ agar-agar kertas antara $\mathrm{pH}$ 8.16 - 9.45 cenderung ke arah basa, hal ini tidak cocok untuk bahan PCA yang menghendaki pH netral atau berkisar pada pH 7. Demikian juga, pada pengamatan secara visual, agar-agar kertas tersebut lebih keruh, dibandingkan dengan tepung agar-agar GS 800, GS 900 dan GS $1000 \mathrm{gr} / \mathrm{cm}^{2}$, sehingga dengan kondisi seperti itu belum menunjukkan hasil yang cocok untuk media Plate Count Agar (PCA), oleh sebab itu pada percobaan formulasi selanjutnya menggunakan bahan tepung agar-agar yang komersial, dengan kode GS 800, GS 900 dan GS $1000 \mathrm{gr} / \mathrm{cm}^{2}$.

Berdasarkan data analisis pada Tabel 1, hasil uji organoleptik, menunjukkan bahwa seluruh contoh uji tepung agar-agar GS 800, GS 900 dan GS 1000, memenuhi syarat, karena nilai organoleptik lebih tinggi dari 7 (SNI 2802:2015). Kadar air berkisar 12.8 - $16.9 \%$, masih kurang dari $22 \%$ berdasarkan SNI 2802:2015.

Tabel 2

Kandungan cemaran logam media uji PCA hasil formulasi

\begin{tabular}{|c|c|c|c|c|}
\hline \multirow[b]{2}{*}{$\begin{array}{l}\text { Kode } \\
\text { Contoh }\end{array}$} & \multicolumn{3}{|c|}{ Parameter Cemaran Logam } & \multirow[b]{2}{*}{$\begin{array}{c}\text { Arsen } \\
\text { (As) }\end{array}$} \\
\hline & $\begin{array}{c}\text { Timbal } \\
(\mathrm{Pb})\end{array}$ & $\begin{array}{l}\text { Kadmium } \\
\text { (Cd) }\end{array}$ & $\begin{array}{c}\text { Raksa } \\
\text { (Hg) }\end{array}$ & \\
\hline F1 GS 800 & 0.27 & 0,02 & $<0.005$ & $<0.013$ \\
\hline $\mathrm{F} 1 \mathrm{G}$ & 0.12 & 0,01 & $<0.005$ & \\
\hline F2 GS 800 & 0.18 & $<0.004$ & $<0.005$ & $<0.013$ \\
\hline F2 GS 900 & 0.10 & 0.004 & $<0.005$ & $<0.013$ \\
\hline
\end{tabular}

Kadar abu dan kadar abu tidak larut dalam air masih memenuhi syarat, demikian juga kandungan pati, gelatin dan protein juga negatif, hal ini menunjukkan bahwa contoh tepung agar-agar tersebut murni tidak ada tambahan bahan lainnya, selain bahan agar-agar. Absorpsi air memenuhi syarat, yaitu mencapai 13 - 14 kali, melebihi dari persyaratan yaitu 5 kali. Demikian pula untuk benda asing, masih di bawah dari $1 \%$. Untuk kehalusan mencapai 100 mesh, telah memenuhi syarat SNI 2802:2015. Sedangkan untuk cemaran logam Timbal (Pb), Kadmium (Cd), Timah (Sn) dan Raksa (Hg) serta Arsen masih memenuhi syarat sebagai bahan media uji berdasarkan India Standart (Specification for Agar Microbiological Grade).

Pada uji pendahuluan untuk percobaan formulasi media PCA yang diuji menggunakan biakan murni bakteri coliform, menunjukkan bahwa jumlah bakteri yang dapat dihitung seperti terlihat pada Tabel 3. Tabel 3 menunjukkan bahwa formula menggunakan bahan tepung agar-agar GS $800 \mathrm{gr} / \mathrm{cm}^{2}$, GS $900 \mathrm{gr} / \mathrm{cm}^{2}$ dan GS $1000 \mathrm{gr} / \mathrm{cm}^{2}$ pada formula simplo maupun duplo dengan percobaan sebanyak 3 kali percobaan, terlihat bahwa jumlah mikroba yang aktif selama inkubasi 48 jam menunjukkan relatif mendekati bahan media uji PCA komersial. Hal ini menunjukkan bahwa tepung agar-agar yang digunakan cocok untuk pembuatan formulasi PCA.

Tabel 3

Hasil uji angka lempeng total formulasi PCA berbahan agar-agar lokal.

\begin{tabular}{|c|c|c|c|c|c|c|}
\hline \multirow{3}{*}{ Kode } & \multicolumn{6}{|c|}{ Jumlah bakteri (koloni) } \\
\hline & \multicolumn{2}{|c|}{ I } & \multicolumn{2}{|c|}{$\overline{\mathrm{II}}$} & \multicolumn{2}{|c|}{ III } \\
\hline & Simplo & Duplo & Simplo & Duplo & Simplo & Duplo \\
\hline A 800 (1) & 12 & 21 & 156 & 147 & 200 & 174 \\
\hline В 900 (1) & 7 & 11 & 136 & 162 & 188 & 189 \\
\hline C 1000 (1) & 11 & 13 & 172 & 184 & 174 & 171 \\
\hline D 800 (2) & 15 & 10 & 129 & 161 & 133 & 185 \\
\hline E 900 (2) & 13 & 18 & 166 & 165 & 161 & 179 \\
\hline F 1000 (2) & 11 & 8 & 142 & 172 & 170 & 181 \\
\hline PCA & 23 & 8 & 186 & 151 & 222 & 204 \\
\hline
\end{tabular}

Secara umum dalam pembuatan media terdapat 3 buah larutan yaitu pepton dengan $\mathrm{pH} 7,9$ sebagai sumber nitrogen yang berfungsi untuk membantu pembiakan media. Pembuatan media ini harus dipersiapkan selama 2-3 minggu (Diliello, 2002). Pada pembuatan berbagai macam media untuk mikroorganisme harus menggunakan bahan yang mengandung banyak protein dengan berbagai 
konsentrasinya sehingga dapat menumbuhkan bakteri (Sandle, 2016).

Untuk memastikan bahwa tepung agar-agar tersebut cocok untuk bahan media uji ALT, perlu dilakukan uji lebih lanjut, yaitu menggunakan uji $\mathrm{T}$ (T-test) pada tingkat signifikansi $5 \%(0.05)$ atau tingkat kepercayaan $95 \%$.

Tabel 4

Hasil uji t-test Formula I dan Formula II, terhadap PCA komersial

\begin{tabular}{|c|c|c|c|}
\hline Formulasi & Thitung & F hitung & Ket \\
\hline \multicolumn{4}{|l|}{$\begin{array}{l}\text { Formulasi I } \\
\text { agar GS } 800\end{array}$} \\
\hline $\begin{array}{l}\text { Konsentrasi } \\
\text { rendah }\end{array}$ & $\begin{array}{l}\text { T hitung }<\mathrm{T} \\
\text { tabel }\end{array}$ & $\begin{array}{l}\text { F hitung }<\text { F } \\
\text { tabel }\end{array}$ & $\begin{array}{l}\text { Tidak beda } \\
\text { nyata }\end{array}$ \\
\hline $\begin{array}{l}\text { Konsentrasi } \\
\text { medium }\end{array}$ & $\begin{array}{l}\text { T hitung }<\mathrm{T} \\
\text { tabel }\end{array}$ & $\begin{array}{l}\text { F hitung }<\text { F } \\
\text { tabel }\end{array}$ & $\begin{array}{l}\text { Tidak beda } \\
\text { nyata }\end{array}$ \\
\hline \multicolumn{4}{|l|}{$\begin{array}{l}\text { Formulasi I } \\
\text { agar GS } 900\end{array}$} \\
\hline $\begin{array}{l}\text { Konsentrasi } \\
\text { rendah }\end{array}$ & $\begin{array}{l}\mathrm{T} \text { hitung }>\mathrm{T} \\
\text { tabel }\end{array}$ & $\begin{array}{l}\text { F hitung }<\text { F } \\
\text { tabel }\end{array}$ & $\begin{array}{l}\text { Berbeda } \\
\text { nyata }\end{array}$ \\
\hline $\begin{array}{l}\text { Konsentrasi } \\
\text { medium }\end{array}$ & $\begin{array}{l}\text { T hitung }<\mathrm{T} \\
\text { tabel }\end{array}$ & $\begin{array}{l}\text { F hitung }<\text { F } \\
\text { tabel }\end{array}$ & $\begin{array}{l}\text { Tidak beda } \\
\text { nyata }\end{array}$ \\
\hline \multicolumn{4}{|l|}{$\begin{array}{l}\text { Formulasi II } \\
\text { agar GS } 800\end{array}$} \\
\hline $\begin{array}{l}\text { Konsentrasi } \\
\text { rendah }\end{array}$ & $\begin{array}{l}\text { T hitung }>\mathrm{T} \\
\text { tabel }\end{array}$ & $\begin{array}{l}\text { F hitung }<\text { F } \\
\text { tabel }\end{array}$ & Berbeda nyata \\
\hline $\begin{array}{l}\text { Konsentrasi } \\
\text { medium }\end{array}$ & $\begin{array}{l}\text { T hitung }<\mathrm{T} \\
\text { tabel }\end{array}$ & $\begin{array}{l}\text { F hitung }<\text { F } \\
\text { tabel }\end{array}$ & $\begin{array}{l}\text { Tidak beda } \\
\text { nyata }\end{array}$ \\
\hline \multicolumn{4}{|l|}{$\begin{array}{l}\text { Formulasi II } \\
\text { agar GS } 900\end{array}$} \\
\hline $\begin{array}{l}\text { Konsentrasi } \\
\text { rendah }\end{array}$ & $\begin{array}{l}\text { T hitung }<\mathrm{T} \\
\text { tabel }\end{array}$ & $\begin{array}{l}\text { F hitung }<\text { F } \\
\text { tabel }\end{array}$ & $\begin{array}{l}\text { Tidak beda } \\
\text { nyata }\end{array}$ \\
\hline $\begin{array}{l}\text { Konsentrasi } \\
\text { medium }\end{array}$ & $\begin{array}{l}\mathrm{T} \text { hitung }>\mathrm{T} \\
\text { tabel }\end{array}$ & $\begin{array}{l}\text { F hitung }<\mathrm{F} \\
\text { tabel }\end{array}$ & Berbeda nyata \\
\hline
\end{tabular}

Tabel 4 merupakan hasil uji $\mathrm{t}$ (t-test) formulasi, untuk analisis perbandingan menggunakan PCA komersial, Tabel 4 memperlihatkan bahwa Formula I (menggunakan bahan baku agar-agar GS 800 $\mathrm{gr} / \mathrm{cm}^{2}$ ), tidak berbeda nyata dibandingkan dengan PCA komersial pada uji penumbuhan biakan murni E. coli, baik konsentrasi rendah maupun medium.

Media PCA termasuk ke dalam media padat. Teknik yang biasa digunakan dalam media padat biasanya berdasarkan jumlah hitungan koloni pada lempeng atau colony forming unit (CFU) dari inokulum standar mikroba. Hitungan koloni dapat digunakan untuk melihat rasio produktifitas yang mengkuantifikasi pertumbuhan relatif dari mikroba pada media yang diujikan dengan pertumbuhan mikroba tersebut secara paralel pada media referensi (Corry et al., 2011). Faktor selektifitas dan spesifitas tertentu menentukan kemampuan kultur media untuk menghambat galur yang tidak diharapkan tumbuh, namun faktor selektifitas ini tidak diaplikasikan pada media PCA.

\section{Kesimpulan}

Hasil analisis viskositas, $\mathrm{pH}$ dan pengamatan secara visual agar-agar kertas yang dibuat, untuk uji coba pendahuluan masih belum sesuai sebagai bahan formulasi pembuatan PCA, namun untuk agar-agar dari rumput laut lokal GS 800, GS 900 dan GS $1000 \mathrm{gr} / \mathrm{cm}^{2}$ memenuhi persyaratan SNI 2802:2015 (SNI Tepung Agar-agar) dan memenuhi persyaratan Spesifikasi Agar-Agar untuk keperluan uji mikrobiologi berdasarkan persyaratan Indian Standard (1973). Sedangkan uji T-test, untuk analisis perbandingan menggunakan PCA komersial, menunjukkan bahwa Formula I (menggunakan bahan baku agar-agar GS 800 $\mathrm{gr} / \mathrm{cm}^{2}$ ), tidak berbeda nyata dibandingkan dengan PCA komersial pada uji penumbuhan biakan murni E. coli, baik konsentrasi rendah maupun medium, sehingga formula I, dapat direkomendasikan sebagai formula terbaik, dibandingkan dengan formula lainnya.

\section{Ucapan terima kasih}

Penulis mengucapkan terima kasih kepada Balai Besar Industri Agro atas dana penelitian yang diberikan pada Tahun 2016.

\section{Daftar Pustaka}

Ansori, Munib. (2015, Juli 9). RI Produsen Rumput Laut Terbesar Dunia Jenis Cottonii. Harian Ekonomi Neraca (Online) Retrieved Agustus, 4, 2018 from http://www.neraca.co.id/article/56119/ri-produsen-rumputlaut-terbesar-dunia-jenis-cottonii

Badan Standardisasi Nasional. (2015). SNI Tepung Agar-Agar (SNI 2802:2015). Badan Standardisasi Nasional, Jakarta.

Corry, J.E., Curtis, G.D. and Baird, R.M. (2011). Handbook of culture media for food and water microbiology. Royal Society of Chemistry.

Diliello, R.L. (2002). Methods in Rood and Dairy Microbiology. New York : Avy Publishing Inc

Direktorat Jenderal Perikanan Budidaya. (2013). Warta Ekspor: Rumput Laut Indonesia. Ditjen PEN/MJL/004/9/2013 September

Fairbrother, R.W. (2014). A Text-Book of Bacteriology : Chapter XXXVII Preparation of Culture Media. Elsevier.

Fardiaz, S. (1993). Analisis Mikrobiologi Pangan Edisi Pertama. Cetakan Pertama. Raja Grafindo Persada, Jakarta.

Hammack, T.S., Feng, P., Amaguana, M., June, G.A., Sherrod, P.S \& Andrews, W.H. (1997). Comparison of Sorbitol McConkey and Hemorraghic coli Agars For Recovery of Escherichia coli 0157; H7 from Brie, Ice Cream, and Wholemilk. J. AOAC Int. 80: $335-340$.

Indian Standard. (1973). Specification for Agar Microbiological Grade. Indian Standard Institution, Manak Bhavan, 9 Bahdur Shah Zafar Marg, New Dehli 110001.

Jarvis, B. (2008). Statistical Aspects of the Microbiological Examination of Foods. $2^{\text {nd }}$ ed. Academic Press, London.

Rakhmawati A. (2012). Penyiapan Media Mikroorganisme, Universitas Negeri Yogyakarta.

Sandle, T. (2016). Pharmaceutical Microbiology : Chapter 5 Microbiological culture media. Elsevier

Sudariastuty, E. (2011). Materi Penyuluhan Perikanan: Pengolahan Rumput Laut. PPKP. Jakarta.

Rahmasari, V. (2008). Pemanfaatan Air Abu Sabut Kelapa dalam Pembuatan Agar-Agar Kertas dari Rumput Laut Gracilaria sp. Skripsi Program Studi Teknologi Hasil Perikanan Fakultas Perikanan dan Kelautan. Institut Pertanian : Bogor. 